\title{
It's the Economy, not European Identity: The Effect of European Identity and Economic Considerations on Public Support for EU Membership in Turkey and Central and Eastern European Countries
}

\section{A. Burcu Bayram*}

\begin{abstract}
:
Turkey has long been characterized as "too big, too poor, too Muslim" to be a European country. This assertion permeated the political debates regarding Turkey's accession to the Union in the early 2000s, leading to a Turkey versus the rest dichotomy: Other candidate countries are European, Turkey is not. A central dimension of this dichotomy was the juxtaposition of public attitudes toward EU membership in Turkey and Central and Eastern European countries (CEECs). A frequently evoked claim during the fifth enlargement of the Union was that the Turkish public supports EU membership due to its expected economic benefits while citizens in CEECs desire membership because they identify as European. In this article, I show that this claim was empirically false. Using data from the Eurobarometer survey for candidate countries, I statistically demonstrate that both Turks and citizens of CEECs supported EU membership for economic reasons. European identity played a negligible role in shaping mass support for EU membership in Turkey and other candidate countries alike. This study makes a central contribution to the existing literature by analyzing the relative impact of European identity and economic considerations on public support for EU membership in Turkey and CEECs. The results fill an important void in the existing scholarship and contribute to ongoing political debates on Turkey's EU membership.
\end{abstract}

Keywords: $\quad$ European Identity, Economy, Public Support, EU membership, Turkey, CEECs

\footnotetext{
*Assistant Professor, University of Texas at Arlington, Department of Political Science, abbayram@uta.edu
} 
It's the Economy, not European Identity:

\section{Introduction}

On its long road to membership in the European Union (EU), Turkey has often been charged with not being European enough. Many have posited that unlike other candidate countries, Turkey is "too big, too poor, too Muslim" to be a European country. ${ }^{1}$ This assertion permeated the political debates regarding Turkey's accession to the Union in the early 2000s, leading to a Turkey versus the rest dichotomy: Other candidate countries are European, Turkey is not.

A central dimension of this dichotomy was the juxtaposition of public attitudes toward EU membership in Turkey and Central and Eastern European countries (CEECs). A frequently evoked claim during the fifth enlargement of the Union was that the Turkish public supports EU membership due to its expected economic benefits while citizens in CEECs desire membership because they identify as European.

Europe started accession negotiations with Turkey in 2005, yet the image of the moneydriven Turkish public continues to negatively influence the views of many EU leaders as well as those of European publics on Turkey's membership. The assumption that Turks had been driven by utilitarian considerations while citizens of CEECs had been guided by their European identity is well alive in current political and popular discourses. In fact, the portrayal of the Turkish public as motivated by pocketbook considerations continues to negatively affect the ongoing accession negotiations. And even though Turkish citizens' support for membership waxed and waned throughout the years, ${ }^{2}$ the contrast between the Turkish and Central and Eastern European publics' motivations for EU membership has remained prominent to date.

In this article, I show that the presumed contrast between the Turkish and Central and Eastern European publics' motivations for EU membership was empirically false. Using data from the Eurobarometer survey for candidate countries, I statistically demonstrate that both Turks and citizens of Bulgaria, Cyprus, Czech Republic, Estonia, Hungry, Latvia, Lithuania, Malta, Poland, Slovakia, and Slovenia primarily supported EU membership because of anticipated instrumental benefits. Identification with Europe played only a marginal role in mass support for EU membership in Turkey and other candidate countries alike. It is the economy, not European identity that drove both Turks and others.

A rich body of scholarship has explored the bases of public attitudes for EU membership in Turkey. ${ }^{3}$ However, only a handful of studies have compared the sources of public support for EU membership in Turkey and CEECs and examined whether the Turkish public's motivations for EU membership differs from those of CEEC publics. ${ }^{4}$ In particular, still missing from the existing literature is a comparative analysis of the role European identity and utilitarian considerations played in Turkey and other candidate countries.

This study makes a central contribution to the existing literature by analyzing the relative impact of European identity and economic considerations on public support for EU membership in Turkey and CEECs. To my knowledge, this is the first study that sheds light on this specific issue. Thus, the results of this work fill an important void in the extant scholarship.

Second, the results of this study should be of particular interest to policy-makers devising Turkey's EU policy and to scholars questioning the notion that Turkey is not European even though it is stuck with Europe. ${ }^{5}$ By providing empirical evidence that the Turkish public's motivations for EU membership did not significantly differ from those of CEECs, the findings of this research help debunk the assumption that Turkey is not European enough, and thus counter the Turkey versus the rest dichotomy.

This paper unfolds in three parts. I start with a discussion of the Turkey versus the rest dichotomy in the fifth enlargement and outline the presumed the contrast between the Turkish and Central and Eastern European publics' motivations for EU membership. I explain that Turkey's quest 
Burcu Bayram

for EU membership was singled out as instrumentally motivated and juxtaposed with CEECs desire for membership driven by European identity. In section two, I develop a model of support for EU membership and statistically test the effect of European identity and economic considerations in Turkey and CEECs. I conclude by sketching the implications of my findings and making suggestions | 18 for future research.

\section{Turkey versus the Rest Dichotomy During the Fifth Enlargement}

Turkey has been waiting at the doorstep of the European Union since the late 1950s. Finally in 2005, when Europe decided to start accession negotiations with Turkey leading to full membership, an anonymous joke began to circulate in Turkey:

The European commissioner for enlargement was informed that Turkey had fulfilled all the political, economic and social requirements for membership and completed the necessary steps in the accession process. The commissioner said: No way! We'd better dissolve the Union right away!

This anecdote is a humorous albeit telling indication of Europe's concerns with Turkey's membership. ${ }^{6}$ Since the application of Turkey to become an associate member of the European Economic Community in 1959, five main factors have been identified as obstacles to Turkey's entrance to the European club: economy, geography, democracy, Cyprus, and identity. ${ }^{7}$ The economic burden Europe would have to shoulder with Turkey's entrance has always been evident. Funneling large amounts of money to Turkey to facilitate its economic development and allowing the Turkish labor to move freely in the European labor market have long troubled the Europeans. ${ }^{8}$

Europe has also not been shy to point to Turkey' geographic location as a source of concern. ${ }^{9}$ Admitting Turkey as a member in effect means extending the borders of Europe to the Middle East, thereby bringing the problems of this volatile region to the heart of the continent. Not surprisingly, keeping Turkey as a buffer between Europe and the Middle East has been an attractive option to the Union. ${ }^{10}$ Perhaps the most vocally articulated impediment to Turkey's accession, however, has been in the political domain. Europe has called into question Turkey's human rights practices and the functioning of democracy in the country, indicating that membership was conditional upon comprehensive improvements to human rights practices and democratic reforms. ${ }^{11}$ Of course, following the Turkish intervention in 1974, the Cyprus question has continued to be a strain on Turkey's relationship with Europe as well. ${ }^{12}$

Between Turkey's original application in 1959 and the mid 1990s, Europe's unease about Turkish membership had largely centered on economy, geography, democracy, and the Cyprus question. Even though Europe implicitly questioned Turkey's fit into the Community as a Muslim majority country, it was careful no to mention identity as an impediment to membership in order not to alienate the Turks.

During the late 1990s, however, the nature of the debates surrounding Turkey's membership went through a visible transformation. The denial of Turkey's application at the Luxembourg Summit in 1997 marked an important turning point in Turco-European relations. Turkey's Muslim identity came to the forefront as a major reason for its potential ineligibility for membership. ${ }^{13}$

Even though Europe officially recognized Turkey as a candidate at the Helsinki Summit in 1999, it continued to imply that Turkey was different from the other candidates of the eastern enlargement. Importantly, Turkey's quest for membership was perceived to be instrumentally motivated. Many European leaders and EU diplomats believed that Turkey was in desperate need of the economic benefits of membership and had no viable foreign policy option in the post-Cold War era other than EU membership. ${ }^{14}$ Accession to the Union was Turkey's best bet although even a loose sense of European identity was not present among the majority of the Turks. This assumption was 
partly bolstered by empirical evidence. For example, according to a nation-wide survey conducted in 2002 by TESEV, a large segment of the Turkish population noted that the most important detriment of EU membership would be loss of Turkey's religious and national identity. ${ }^{15}$

In contrast, admitting CEECs to the Union symbolized brining them "back home". ${ }^{16}$ European leaders and EU diplomats saw CEECs' desire for membership as a natural foreign policy choice. CEECs were seeking membership because they were European. Accession to the Union not only marked the end of their imprisonment in the Soviet bloc during the Cold War but also marked the revitalization of their European identity.

That the Turkish public hoped for EU membership due to its anticipated economic benefits while citizens in CEECs desired it because they identify as European is an abiding claim. In this article, I statistically test the veracity of this claim and show that it is wrong. I demonstrate that Turks' motivations for membership were not any more instrumental than those of other candidate countries. Both Turkish people and citizens of CEECs supported EU membership for economic reasons. European identity played only a minimal role in mass support for EU membership both in Turkey and other candidates.

\section{Data and Variables}

In order to test the relative effects of European identity and economic considerations on public' support for accession to the EU, I use data from the Eurobarometer survey (2003.4) for candidate countries. The unit of analysis is the individual respondent. The candidate countries included in the analysis are Turkey, Bulgaria, Cyprus, Czech Republic, Estonia, Hungry, Latvia, Lithuania, Malta, Poland, Slovakia, and Slovenia. I estimate 12 linear regression models for each of the candidates in the dataset. ${ }^{17}$

The dependent or outcome variable captures a respondent's support for EU membership. Participants were asked indicate their support by the following question: "Generally speaking, do you think that (insert the name of the respondent's country)' membership of the European Union would be...." Response options included "a good thing (coded 3), "neither a good nor a bad thing (coded 2), and "a bad thing (coded 1)." The distribution of the publics' views on this question is presented in Table 1.

\section{Table 1. Mass Support for EU membership in Candidate Countries, 2002-2003.}

\begin{tabular}{llll} 
Country & $\begin{array}{l}\text { Membership will be a } \\
\text { GOOD Thing }\end{array}$ & $\begin{array}{l}\text { Membership will be a } \\
\text { BAD Thing }\end{array}$ & $\begin{array}{l}\text { Membership will be } \\
\text { NEITHER good } \\
\text { NOR a bad thing }\end{array}$ \\
\hline Turkey & $70.4 \%$ & $11.9 \%$ & $17.7 \%$ \\
Bulgaria & $78.2 \%$ & $3.2 \%$ & $18.6 \%$ \\
Cyprus & $61.2 \%$ & $11.4 \%$ & $27.4 \%$ \\
Czech Republic & $51.4 \%$ & $14.3 \%$ & $34.3 \%$ \\
Estonia & $43.9 \%$ & $17.0 \%$ & $39.1 \%$ \\
Hungary & $63.9 \%$ & $10.1 \%$ & $25.9 \%$ \\
Latvia & $49.8 \%$ & $17.2 \%$ & $33.0 \%$ \\
Lithuania & $62.9 \%$ & $9.1 \%$ & $28.0 \%$ \\
Malta & $64.6 \%$ & $15.6 \%$ & $19.8 \%$ \\
Poland & $56.4 \%$ & $13.9 \%$ & $29.7 \%$ \\
Slovakia & $59.3 \%$ & $8.2 \%$ & $32.5 \%$ \\
Slovenia & $52.5 \%$ & $7.2 \%$ & $40.3 \%$ \\
\hline
\end{tabular}


Burcu Bayram

Notes: Table entries reflect the percentage of respondents who indicated that membership in the EU will be a good thing, a bad thing, or neither a good or a bad thing

The first explanatory factor is European identity. Although publics' attitudes toward further integration has long been characterized as "permissive consensus" 18 , the importance of public support for European integration is now evident. ${ }^{19}$ Important studies have established that citizens who identify with Europe are more likely to support European integration or favor the inclusion of their country in the Union..$^{20}$

To capture respondents' identification with Europe, I rely on two questions in the survey instrument. Participants were asked to indicate how proud they are to be European. The endpoints of the response scale were marked by "Very proud (coded 4)" and "Not at all proud (coded 1)." Respondents were also asked to specify how they see their identity in the near future. Response options included "European only (coded 4)", European and nationality (coded 3)", "Nationality and European (coded 2)" and "Nationality only (coded 1)." I have created a composite index gauging a respondent's sense of identification with Europe based using the identity and pride questions. ( $\alpha=$ 0.68). ${ }^{21}$ The variable European Identity captures an individual's strength of identification with Europe. It ranges from 1 to 4 , where higher values indicate stronger identification with Europe. ${ }^{22}$

Utilitarian explanations posit that public support for EU membership is shaped by the expected economic benefits of integration. ${ }^{23}$ A number of studies have found that individuals who believe that their personal economic situation and their country's overall economic standing will improve as a result of EU membership are more likely to be in favor of membership. ${ }^{24}$ Building upon these approaches, I develop two variables that capture the importance of the instrumental benefits of EU membership. The first variable measures respondents' beliefs about the material benefits EU membership will bring to their country as a whole. The variable Country Gains is an index of two items that respectively asked respondents about their views on the overall economic prospects of their country and on the future of the employment opportunities $(\alpha=0.78)$. This variable ranges from "things are going to be worse" (coded 1), "stay the same" (coded 2) or "get better" (coded 3).

The second economic variable measures the extent to which an individual believes that EU membership will improve his or her personal economic status. The variable Personal Gains is an index of three questions, tapping respondents' expectations for improvement in their life, in the financial status of their household, and their personal job situation in the future $(\alpha=0.76)$. It ranges from "things are going to be worse" (coded 1), "stay the same" (coded 2) or "get better" (coded 3).

My analysis also includes a series of control variables. In addition to European identity and material gains, I take into account the factors that can conceivably influence public support for EU membership. First is nationalism. It is likely that nationalist individuals are less interested in seeing their country become part of the EU because they fear that EU membership will lead to loss of national identity. ${ }^{25}$ To investigate this possibility, I created a Nationalism variable that is coded 1 if respondents indicated that they only identify with their nation, 0 if they expressed identifying with Europe as well as with their nation.

Second, I take into consideration multiculturalism. Important works have noted that individuals who are acceptant of different cultures tend to be more supportive of joining such a diverse community as Europe. ${ }^{26}$ To gauge multiculturalism, I rely on a question that asked respondents whether or not Europe would be culturally richer with the inclusion of more member countries. Multiculturalism is a dichotomous variable coded 1 if respondents noted that they "Tend to agree", 0 if they answered "Tend to Disagree."

Some scholars have argued that individuals with advanced cognitive capacity are more supportive of EU membership than those with lower levels of cognitive capacity because they are intellectually better equipped to understand the complex issues involved in European integration. ${ }^{27}$ The concept of opinion leadership has typically been used to tap people's cognitive skills. ${ }^{28}$ The 
It's the Economy, not European Identity:

argument here is that individuals who are opinion leaders in their respective communities are aware of EU related matters and frequently discuss these issues with people in their social networks, suggesting higher levels of cognitive capacity. Therefore, to measure cognitive capacity, I created an index of opinion leadership composed of six questions $(\alpha=0.87)$. The first five items capture the frequency at which a participant discusses political matters with friends, their partner, other relatives, fellow workers, and other people in general. Response options for these measures are anchored by "Frequently (coded 4)" and "Never (coded 1)." The sixth item asked: "When you hold a strong opinion, do you ever find yourself persuading your friends, relatives, or fellow workers to share your views? Does this happen...?" The end points of the response scale for this question are "Often (coded 4)" and "Never (coded 1)." The variable Cognitive Capacity represents a participant's average score on these six questions, where higher values (4-1) indicate advanced cognitive capacity.

Further, I control for two key political factors: satisfaction with democracy and support for the national government. Some scholars have argued that individuals who are not satisfied with the functioning of democracy in their country tend to be more supportive of EU membership. ${ }^{29}$ This is because these people are likely to see the political conditions for membership as a means to decrease the democracy deficit in their country. However, other scholars have made the opposite claim, arguing that citizens satisfied with the functioning of democracy in their country are more likely to support EU membership. ${ }^{30}$ Thus, it is important to control for citizens' satisfaction with democracy in the estimation of the models. The variable Satisfaction with democracy taps a respondent's level of satisfaction with the functioning of democracy in their country, with response options ranging from "Very satisfied (coded 4)" to "Not at all satisfied (coded 1)."

Extant research has shown a positive relationship between citizens' support for their national government and EU membership. ${ }^{31}$ Scholars have explained this association by the projection argument. Citizens who disapprove of the government support EU membership less if accession to the EU is a key goal of the government. To measure respondents' support for their government, I rely on a commonly used indicator that captures trust in the national government. This is a sensible proxy as individuals who trust their government are also likely to approve of it. Support for Government is a dummy variable coded 1 if respondents indicating trusting the government and 0 if they expressed distrust.

Finally, I control for conventional socio-economic and demographic factors. Income is an interval variable measuring a respondent's household income in deciles. Education measures the years of education a respondent has completed. Age measures a respondent's age in years, and finally Female is a dummy variable coded 1 if the respondent is female, 0 if male.

\section{Results}

Table 2 displays the results. Each of the 12 estimated models are statistically significant and, on average, explain about $60 \%$ of the variance in mass support for EU membership, indicating good statistical performance. ${ }^{32}$ The findings clearly show that both Turks and publics in CEECs favor EU membership primarily for economic reasons. The effect of European identity on support for membership is notably small, almost negligible, both in Turkey and CEECs. In fact, relative to Bulgarians, Estonians, Slovaks, and the Czechs, Turks place more emphasis on European identity. These findings indicate that the Turkish public is no more instrumentally motivated than citizens of other candidate countries. 
Burcu Bayram

Table 2. Citizens both in Turkey and CEECs support EU membership for economic reasons, not because they identify as European.

\begin{tabular}{|c|c|c|c|c|c|c|c|c|c|c|c|c|c|c|}
\hline & \multicolumn{2}{|c|}{ Turkey } & \multicolumn{2}{|c|}{ Bulgaria } & \multicolumn{2}{|c|}{ Cyprus } & \multicolumn{2}{|c|}{ Czech Rep. } & \multicolumn{2}{|c|}{ Estonia } & \multicolumn{2}{|c|}{ Hungary } & \multicolumn{2}{|c|}{ Latvia } \\
\hline & Coef. & $\begin{array}{l}\text { Sd. } \\
\text { Error }\end{array}$ & Coef. & $\begin{array}{l}\text { Sd. } \\
\text { Error }\end{array}$ & Coef. & $\begin{array}{l}\text { Sd. } \\
\text { Error }\end{array}$ & Coef. & $\begin{array}{l}\text { Sd. } \\
\text { Error }\end{array}$ & Coef. & $\begin{array}{l}\text { Sd. } \\
\text { Error }\end{array}$ & Coef. & $\begin{array}{l}\text { Sd. } \\
\text { Error }\end{array}$ & Coef. & $\begin{array}{l}\text { Sd. } \\
\text { Error }\end{array}$ \\
\hline Country Gains & $.988 *$ & .06 & $.847 *$ & .06 & $.922 *$ & .09 & $.751 *$ & .07 & $.716^{*}$ & .06 & $1.09 *$ & .06 & $.886^{*}$ & .06 \\
\hline Personal Gains & $.292 *$ & .05 & $.173 *$ & .03 & $.233 *$ & .07 & $.319^{*}$ & .06 & $.359 *$ & .06 & $.187 *$ & .04 & $.379 *$ & .06 \\
\hline European Identity & $.083 *$ & .02 & $.039 *$ & .02 & $.098^{*}$ & .04 & $.078 *$ & .03 & $.019 *$ & .03 & .026 & .03 & $.097 *$ & .03 \\
\hline Nationalism & $-.127^{*}$ & .03 & $-.085^{*}$ & .03 & $-.025^{*}$ & .07 & $-.060^{*}$ & .05 & $-.132 *$ & .05 & $-.06 * *$ & .04 & -.012 & .05 \\
\hline Multiculturalism & $.120 *$ & .04 & $.202 *$ & .04 & $.316^{*}$ & .09 & $.197 *$ & .05 & $.167 *$ & .05 & $.132 *$ & .05 & .072 & .06 \\
\hline $\begin{array}{l}\text { Satisfaction with } \\
\text { Democracy }\end{array}$ & .016 & .02 & -.010 & .02 & -.008 & .04 & $-.095^{*}$ & .03 & $.055^{* *}$ & .03 & $.063 *$ & .03 & .002 & .03 \\
\hline Cognitive Capacity & .004 & .02 & $.057 *$ & .02 & .009 & .05 & .004 & .04 & $.085 *$ & .037 & .012 & .03 & .033 & .03 \\
\hline Support of Government & .030 & .03 & $.042 * *$ & .03 & $.101^{* *}$ & .071 & .039 & .05 & $.109 *$ & .05 & $.075^{* *}$ & .04 & $.193 *$ & .05 \\
\hline Income & $.074 * *$ & .04 & .003 & .01 & .008 & .03 & .016 & .02 & $.066^{*}$ & .02 & .025 & .02 & .004 & .02 \\
\hline Education & .011 & .02 & .022 & .02 & .037 & .04 & $.055 * *$ & .03 & .012 & .03 & .003 & .02 & .012 & .03 \\
\hline Female & .023 & .03 & .010 & .02 & .056 & $.05^{*}$ & .141 & .04 & -.033 & .04 & .006 & .03 & - & .04 \\
\hline Age & .001 & .001 & .000 & .001 & .001 & .002 & .002 & .02 & $.002 * *$ & .002 & .001 & .001 & $\begin{array}{l}.08^{* *} \\
.003^{*}\end{array}$ & .002 \\
\hline Adjusted $\mathrm{R}^{2}$ & .645 & & .508 & & .563 & & .662 & & .617 & & .685 & & .625 & \\
\hline
\end{tabular}


Table 2. Continued

\begin{tabular}{|c|c|c|c|c|c|c|c|c|c|c|}
\hline & \multicolumn{2}{|c|}{ Lithuania } & \multicolumn{2}{|l|}{ Malta } & \multicolumn{2}{|l|}{ Poland } & \multicolumn{2}{|c|}{ Slovakia } & \multicolumn{2}{|c|}{ Slovenia } \\
\hline & Coef. & $\begin{array}{l}\text { Sd. } \\
\text { Error }\end{array}$ & Coef. & $\begin{array}{l}\text { Sd. } \\
\text { Error }\end{array}$ & Coef. & $\begin{array}{l}\text { Sd. } \\
\text { Error }\end{array}$ & Coef. & $\begin{array}{l}\text { Sd. } \\
\text { Error }\end{array}$ & $\begin{array}{l}\text { Coef. } \\
\qquad \mid 23\end{array}$ & $\begin{array}{l}\text { Sd. } \\
\text { Error }\end{array}$ \\
\hline Country Gains & $1.246^{*}$ & .03 & $1.031 *$ & .04 & $.834 *$ & .06 & $.665^{*}$ & .06 & $.532 *$ & .06 \\
\hline Personal Gains & $.189 *$ & .04 & $.281^{*}$ & .05 & $.196^{*}$ & .06 & $.152 *$ & .05 & $.206^{*}$ & .06 \\
\hline European Identity & .003 & .03 & $.092 * *$ & .04 & $.117^{*}$ & .03 & $.073 *$ & .03 & $.124 *$ & .04 \\
\hline Nationalism & -.020 & .04 & -.069 & .06 & $-.067 *$ & .05 & $-.167 *$ & .04 & $-.118 *$ & .05 \\
\hline Multiculturalism & $.144 *$ & .05 & .024 & .06 & $.226^{*}$ & .06 & $.237^{*}$ & .05 & .065 & .06 \\
\hline $\begin{array}{l}\text { Satisfaction with } \\
\text { Democracy }\end{array}$ & -.015 & .02 & .003 & .04 & .014 & .03 & .007 & .02 & $.120^{*}$ & .03 \\
\hline Cognitive Capacity & .016 & .03 & .010 & .04 & .023 & .04 & $.071^{*}$ & .03 & $.022 *$ & .04 \\
\hline Support of Government & $.071 * *$ & .04 & $.186^{*}$ & .07 & $.106^{* *}$ & .06 & .005 & .04 & .027 & .05 \\
\hline Income & .001 & .02 & .005 & .02 & .018 & .02 & $.034 * *$ & .02 & .018 & .02 \\
\hline Education & .025 & .02 & .025 & .03 & .018 & .03 & .023 & .03 & $.043 * *$ & .03 \\
\hline Female & -.040 & .03 & $.070 * *$ & .05 & $-.109 *$ & .04 & -.051 & .03 & $-.090 * *$ & .05 \\
\hline Age & .000 & .001 & .001 & .02 & -.022 & .002 & .001 & .001 & .003 & .002 \\
\hline Adjusted $\mathrm{R}^{2}$ & .701 & & .762 & & .601 & & & 549 & & .428 \\
\hline
\end{tabular}


Burcu Bayram

Publics in all candidate countries care first and foremost about the material benefits of EU membership. In all the models, the variable Country Gains has the largest coefficient. This demonstrates that respondents who believe that EU membership will bring economic benefits to their country are significantly more supportive of EU membership. As Turks' belief that Turkey will gain economically gain from EU membership increases by a unit, there is a 0.988 unit increase in support for membership. In Bulgaria, Cyprus, Latvia, and Poland, there is a similar effect. The importance placed on economic gains to the country is largest in Lithuania (1.246) and smallest in Slovenia (0.532).

Similarly, anticipated personal economic gains play a major role in shaping participants' support for membership. The variable Personal Gains has the second largest coefficient in all of the estimated models. In Turkey, for a unit increase in respondents' expectations that their personal economic status will improve, there is a 0.292 increase in support for accession to the EU. A similar effect exists in the Czech Republic, Estonia, Latvia, and Malta. Compared to other countries, the emphasis respondents place on personal economic gains is largest in Estonia (0.319) and smallest in Slovakia (0.152).

European identity has a strikingly small effect on support for EU membership in Turkey and other candidate countries. In Turkey, as identification with Europe increases by one point, support for EU membership rises by 0.08 points. This is a very small substantive effect. However, this outcome is by no means unique to Turkey. In Bulgaria, the Czech Republic, Estonia, Hungary, Slovakia and Lithuania, the effect of European identity on respondents' support for EU membership is smaller than it is in Turkey. On average, in Slovakia, the impact of European identity on the support for membership is 0.07, in Bulgaria, it is 0.039, in the Czech Republic, it is 0.07, in Estonia it is 0.02. The coefficient for the European identity variable fails to reach statistical significant in Hungary and Lithuania, showing that in these countries citizens' views on EU membership are not affected by identity.

In Slovenia, Malta, Poland, Cyprus, and Latvia, identification with Europe has a slightly greater impact on mass support for membership. For one unit increase in identification with Europe, support for EU membership increases by about 0.10 in Cyprus, Latvia, and Malta. In Poland, there is about a 0.2 points increase. Even though the statistical effect of European identity is larger in these cases, its substantive effect is again considerably small compared to that of expected economic benefits.

Among the control variables included in the model estimations, nationalism and multiculturalism stand out. Nationalist individuals are significantly less supportive of membership in the EU. The substantive effect of nationalism is largest in Slovakia (-0.167) and smallest in Cyprus (0.025). In Turkey, for a unit increase in nationalism, there is a 0.127 points decrease in support for accession to the EU. The effect is comparable to those observed in Estonia and Slovenia. In Latvia, Lithuania, and Malta, the impact of nationalism is not statistically significant, indicating no relationship with support for EU membership.

Results also indicate that multiculturalism plays a large role in shaping citizens' support for EU membership in candidate countries expect in Latvia, Malta, and Slovenia. Relative to European identity, the effect of multiculturalism is notably larger in all countries including Turkey. Findings for satisfaction with democracy, cognitive capacity, income, education and demographic variables vary across the models, and when they reach statistical significance, their substantive effects are small.

In sum, the results reliably indicate that controlling for all else, what really shaped citizens' support for EU membership are economic considerations. Identification with Europe had a virtually inconsequential impact on support for membership in Turkey and other candidates alike. Therefore, the claim that Turks were driven by utilitarian factors whereas others were motivated by their European identity has no empirical validity. 
It's the Economy, not European Identity:

\section{Conclusion}

In this study, I have compared the relative effect of European identity and economic considerations on public support for EU membership in Turkey and CEECs candidate countries. Using data from the Eurobarometer survey for candidate countries, I have demonstrated that citizens in Turkey and CEECs favored membership for economic reasons not because they identify as European. This result inverts the alleged contrast between the Turkish and CEEC publics' motivations for membership and thus challenges the Turkey versus the rest dichotomy. Turkish citizens supported EU membership because they believed that being part of the Union would bring economic benefits to Turkey as well as improve their own financial situation. But Turkey is no exception. Citizens in CEECs equally valued the same economic considerations. Contrary to what Europe might want to believe, identification with Europe did not exert a meaningful effect on public support for EU membership in post-communist countries.

Even though there is a growing body of research on Turkish-EU relations, little has been done to compare Turkish peoples' attitudes toward membership with other countries' publics. This study is among the few works that offers a comparative analysis of public positions on EU membership.

The analysis presented in this study reveals that the determinants of Turkish citizens' support for EU membership were remarkably similar to those of citizens in CEECs. What shapes public support was material considerations across all candidate countries, not European identity. Thus, the claim that Turks' desired for membership for material reasons but CEECs sought membership because of their European identity cannot be sustained. This result contributes to a fuller understanding of Turkey's relationship with the EU as well as engages important policy debates regarding Turkey's candidacy.

Future studies can complement the findings of this research by in-depth case studies and further qualitative and quantitative analysis. Additional comparative examinations how the Turkish public and citizens of other candidate countries approach EU membership will also advance our understanding of what shapes mass support for joining the Union.

\section{Notes}

\footnotetext{
${ }^{1}$ Süddeutsche Zeitung, 29 March 2010. See also Deutsche Welle, 18 December 2004. Günes Becerik, "Turkey’s Accession to the EU: A Test Case for the Relevance of Identity," Turkish Policy Quarterly 5, no. 4 (2006); Efe Çaman and Kenan Dağc1, "Avrupa Birliği - Türkiye İlişkilerinde Türk ve Türkiye İmajı" / "Image of Turkey in the EU - Turkey Relations: European Identity And The Problem of Turkey's Belongings to Europe", International Joint Conference, 10th Knowledge Economy and Management Congress, Istanbul, (08-10 November 2012); Samuel, P. Huntington, The Clash of Civilizations and the Remaking of World Order. (New York: Touchstone, 2002).

Heinz Kramer, "Turkey and the EU: The EU's Perspective," Insight Turkey 8, no. 4 (2006): 24-32; Meltem Müftüler-Bac, "The Never-Ending Story: Turkey and the European Union," Middle Eastern Studies 34, no. 4 (1998): 240-258.

${ }^{2}$ Ali Carkoglu, "Who Wants Full Membership? Characteristics of Turkish Public Support of EU Membership," in Turkey and the European Union: Domestic Politics, Economic Integration and International Dynamics, eds. Ali Carkoglu and Barry Rubin (London and Oregon: Frank Cass, 2003), 171-195; Ali Carkoglu and Çiğdem Kentmen, "Diagnosing Trends and Determinants in Public Support for Turkey's EU Membership" South European Society and Politics 16, no. 3 (2011): 365-379.

${ }^{3}$ Gizem Arikan, "Attitudes Towards the European Union in Turkey: The Role of Perceived Threats and Benefits," Perceptions 17, no. 3 (2012): 81-103; Carkoglu, “Who Wants Full Membership?”; Özlem Elgün and
} 
Burcu Bayram

Erik R. Tillman, "Exposure to European Union Policies and Support for Membership in The Candidate Countries," Political Research Quarterly 60, no. 3 (2007): 391-400.

${ }^{4}$ Çigdem Kentmen, "Comparing Individual Attitudes about EU Membership in Turkey and in Post-Communist | 26 Central and Eastern European Countries," All Azimuth 1, no. 2 (2012): 5.

${ }^{5}$ Bulent Aras and Salih Bicakci. "Europe, Turkey and the Middle East: Is Harmonisation Possible?" East European Quarterly 40, no. 3 (2006): 367; Nilay Baycar, "Turkish Cultural Identity: A European Identity," Turkish Journal of Politics (2013): 5; Efe Çaman, "Türkische Außenpolitik Zwischen EU-Integration und Regionaler Orientierung," in Südosteuropa Mitteilungen 3 (2006): 16-31; Kenan Dagci, "Turkey's Integration Process into the EU and Its Implication to Turkey's Foreign Policy," Proc. 1st (Int.) Scientific Conference "Changes In Social And Business Environment," Panevezys, 17-19, Panevezys-Lithuania, 2006; Bülend Aydın Ertekin, "Could Turkey Be a Dominant Regional Power?: The Rise of Turkey as a Country of Middle-East and Europe," Alternatives: Turkish Journal of International Relations 11, no. 1 (2012): 11 no.1; Hasan Kösebalaban, "The Permanent 'Other'? Turkey and the Question of European Identity," Mediterranean Quarterly 18, no. 4 (2007): 87-111; Bahar Rumelili, "Turkey: Identity, Foreign Policy, and Socialization in a Post-Enlargement Europe," European Integration 33, no. 2 (2011): 235-249; Martina Warning and Tuncay Kardaş, "The Impact of Changing Islamic Identity on Turkey's New Foreign Policy," Alternatives: Turkish Journal of International Relations 10, no. 2-3 (2011): 123-140.

${ }^{6}$ Atilla Eralp and Özgehan Şenyuva (eds.), Türkiye - AB İlişkilerinin Tarihsel Gelişimi ve Dönüşümü, Haşimi, Cemal (İstanbul: Avrupa ve Avrupa Birliği, 2011).

${ }^{7}$ Nergis Canefe and Mehmet Ugur (eds.), Turkey and European Integration: Accession Prospects and Issues (London: Routledge, 2004); Meltem Müftüler-Bac, "Turkey in the EU's Enlargement Process: Obstacles and Challenges," Mediterranean Politics 7, no. 2 (2002): 79-95; Ziya Öniş, "Luxembourg, Helsinki and Beyond: Towards an Interpretation of Recent Turkey-EU Relations," Government and Opposition 35, no. 04 (2000): 463-483; C. Rumford, "From Luxembourg to Helsinki: Turkey and the Politics of EU Enlargement and the Prospects of Accession," Contemporary Politics 6 no. 4 (2000): 331-343; Frank Schimmelfennig, "Entrapped Again: The Way to EU Membership Negotiations with Turkey," International Politics 46, no. 4 (2009): 413431. See also the European Commission's document on Turkey's membership, which clearly states that because of its geography, population, size, and cultural and religious characteristics, Turkey's accession would be different from previous enlargements. Available at http://ec.europa.eu/enlargement/archives/pdf/key documents/2004/issues_paper_en.pdf. (accessed: June 1 2015).

${ }^{8}$ Harry Flam, "Turkey and the EU: Politics and Economics of Accession," CESifo Economic Studies 50, no. 1 (2004): 171-210; Lauren M. McLaren, "Explaining Opposition to Turkish Membership of the EU," European Union Politics 8, no. 2 (2007): 251-278; Frank Schimmelfennig, Stefan Engert, and Heiko Knobel, "Costs, Commitment and Compliance: The Impact of EU Democratic Conditionality on Latvia, Slovakia and Turkey," Journal of Common Market Studies 41, no. 3 (2003): 495-518.

${ }^{9}$ Pinar Bilgin, "A Return to 'Civilisational Geopolitics' in the Mediterranean? Changing Geopolitical Images of the European Union and Turkey in the Post-Cold War Era," Geopolitics 9, no. 2 (2004): 269-291; Thomas Diez, "Europe's Others and the Return of Geopolitics," Cambridge Review of International Affairs 17, no. 2 (2004): 319-335; John Redmond, "Turkey and the European Union: troubled European or European trouble?" International Affairs 83, no. 2 (2007): 305-317.

${ }^{10}$ Carl Dahlman, "Turkey's Accession to the European Union: The Geopolitics of Enlargement," Eurasian Geography and Economics 45, no. 8 (2004): 553-574; Müftüler-Bac, "Turkey in the EU's Enlargement Process".

${ }^{11}$ Bülent Aras and Bülent Gökay, "Turkey after Copenhagen: Walking a Tightrope," Journal of Southern Europe and the Balkans Online 5, no. 2 (2003): 147-163; Juergen Gerhards and Silke Hans, "Why not Turkey? Attitudes towards Turkish Membership in the EU among Citizens in 27 European Countries," Journal of Common Market Studies 49 (2011): 1- 26; William Hale, "Human Rights, the European Union and the Turkish Accession Process," Turkish Studies 4, no. 1 (2003): 107-126; Saban Kardas, "Human Rights and Democracy Promotion: The Case of Turkey-EU Relations," Alternatives: Turkish Journal of International Relations 1, no. 3 (2002): 136-50; Schimmelfennig/Engert/Knobel, "Costs, Commitment and Compliance".

12 Öniş, "Luxembourg, Helsinki and Beyond"; Semin Suvarierol, "The Cyprus Obstacle on Turkey's Road to Membership in the European Union," Turkish Studies 4, no. 1 (2003): 55-78.

${ }^{13}$ Mirela Bogdani, Turkey and the Dilemma of EU Accession: When Religion Meets Politics, (New York: IB Tauris, 2010); Yucel Bozdaglioglu, Turkish Foreign Policy and Turkish Identity: A Constructivist Approach 
It's the Economy, not European Identity:

(New York and London: Routledge, 2003); Huntington, Clash of Civilizations; Müftüler-Bac, "The Never-Ending Story"; Kevin Robins, "Interrupting Identities: Turkey/Europe," Questions of Cultural Identity, eds. Stuart. Hall and Paul du Gay (London: Sage 1997), 61-86; Nuri A. Yurdusev, "The Formation of European Identity and the Turkish Identity," in Turkey and Europe, ed A. Eralp (Ankara: Imge 1997), 17-87.

${ }^{14}$ Canan Balkır, "Turkey's Road to EU Membership: Economic Outlook," Köz-Gazdaság Special Issue 3 (2010): 1-16; Meltem Müftüler-Bac, “Through the Looking Glass: Turkey and Europe,” Turkish Studies 1 no. 1 (2000): 21-35.

${ }^{15}$ Carkoglu, "Who Wants Full Membership?"

${ }^{16}$ I. Pavlovaite, "Being European by Joining Europe: Accession and Identity Politics in Lithuania," Cambridge Review of International Affairs 16 no. 2 (2003): 239-255; Ole Weaver, "Explaining Europe by Decoding Discourses," in Explaining European Integration, ed. Anders Wivel (Copenhagen: Copenhagen Political Studies, 1998), 100-146; Iris M. Young, Inclusion and Democracy (Oxford: Oxford University Press, 2000); S. Togan and V. N. Balasubramanyam (eds.), Turkey and Central and Eastern European Countries in Transition: Towards Membership of the EU (New York: St. Martin's Press, 2001).

${ }^{17}$ The data and the codebook describing the questions are available for academic and public use from the Interuniversity Consortium for Political and Social Research (ICPSR) at http://www.icpsr.umich.edu/icpsrweb/ICPSR/studies/4056 and Leibniz Institute for Social Science at http://zacat.gesis.org.

${ }^{18}$ Liesbet Hooghe and Gary Marks, "A Postfunctionalist Theory of European Integration: From Permissive Consensus to Constraining Dissensus," British Journal of Political Science 39, no. 01 (2009): 1-23; Andrew Moravcsik, "Negotiating the Single European Act: National Interests and Conventional Statecraft in the European Community," International Organization 45, no. 01 (1991): 19-56; Christopher J. Anderson and Karl C. Kaltenthaler, "The Dynamics of Public Opinion toward European Integration, 1973-93." European Journal of International Relations 2, no. 2 (1996): 175-199.

${ }^{19}$ Neil Fligstein, Euroclash: The EU, European Identity, and the Future of Europe (Oxford and New York: Oxford University Press, 2008); Thomas Risse, "Neofunctionalism, European Identity and the Puzzles of European Integration," Journal of European Public Policy 12 no. 2 (2005): 291-309.; Hooghe/Marks, "A Postfunctionalist Theory".

${ }^{20}$ Hajo G. Boomgaarden, Andreas R.T. Schuck, Matthijs Elenbaas, and Claes H. De Vreese, "Mapping EU Attitudes: Conceptual and Empirical Dimensions of Euroscepticism and EU Support," European Union Politics 12, no. 2 (2011): 241-266; Jack Citrin and John Sides, "More than Nationals: How Identity Choice Matters in the New Europe," in Transnational Identities: Becoming European in the EU, ed. Richard Herrmann, Thomas Risse, and Marilynn Brewer (USA and UK: Rowman and Littlefield, 2004): 161-185; Neil Fligstein, Alina Polyakova, and Wayne Sandholtz, "European Integration, Nationalism and European Identity," Journal of Common Market Studies 50, no. 1 (2012): 106-122; Thomas Risse, "The Euro between National and European Identity," Journal of European Public Policy 10, no. 4 (2003): 487-505.

${ }^{21}$ Cronbach's alpha is an indicator of the reliability of an index. Values closer to 1 indicate high reliability; values around 0.4-0.5 indicate moderate reliability. A value of 0 indicates lack of reliability.

${ }^{22}$ Names of explanatory variables are presented in italics throughout the text.

${ }^{23}$ Cristopher Anderson, "When in Doubt, Use Proxies: Attitudes Towards Domestic Politics and Support for European Integration," Comparative Political Studies 31 no.5 (1998): 569-601; Adam Brinegar, Seth Jolly, Herbert Kitschelt, "Varieties of Capitalism and Political Divides over European Integration," European Integration and Political Conflict, eds. Garry Marks and Marco R. Steenbergen (Cambridge: Cambridge University Press, 2004), 62-89; Matthew Gabel and Harvey Palmer, "Understanding Variation in Public Support for European Integration," European Journal of Political Research 27 no.1 (1995): 3-19.

${ }^{24}$ Gabel/Palmer, "Understanding Variation "; Richard C. Eichenberg and Russell J. Dalton, "Europeans and the European Community: The Dynamics of Public Support for European Integration," International Organization 47 no. 7 (1993): 507-534; Liesbet Hooghe and Garry Marks, Does Identity or Economic Rationality Drive Public Opinion on European Integration (PS Online 2004) available at: www.apsanet.org (accessed: June 1 2015); Robert Rohrschneider, "The Democracy Deficit and Mass Support for an EU-Wide Government," in American Journal of Political Science 46 no.2 (2002): 463-475; Richard Rose and William T. Mishler, "Mass Reaction to Regime Change in Eastern Europe: Polarization or Leaders and Laggards," British Journal of Political Science 24 no.2 (1994): 159-182; Alasdair Smith and Hellen Wallace, "The European Union: Toward a Policy for Europe," International Affairs 70 (1994): 429-444. 
${ }^{25}$ Sean Carey, "Undivided Loyalties: Is national Identity an Obstacle to European Integration?" European Union Politics 3 no. 4 (2002): 387-413; Liesbet Hooghe and Gary Marks, "Calculation, Community and Cues: Public Opinion on European integration," European Union Politics 6 no. 4 (2005): 419-443.

| $28 \quad{ }^{26}$ Hooghe/Marks, Does Identity or Economic Rationality Drive Public Opinion.

${ }^{27}$ Roland Inglehart, "Cognitive Mobilization and European Identity," Comparative Politics 3 no.1 (1970): 4570; Joseph. H. Janssen, "Post-Materialism, Cognitive Mobilization and Support for European Integration," British Journal of Political Science 21 (1991): 443-468.

${ }^{28}$ Hooghe/Marks, "Calculation, Community and Cues".

${ }^{29}$ N. L. Benolken, "The Path towards Integration: Public Support for European Union among the Countries of Central and Eastern Europe," Critique: A Worldwide Journal of Politics Spring (2003): 1-19; Goeffrey Evans and Stephen Whitefiled, "The Politics and Economics of Democratic Commitment: Support for Democracy in Transition Societies," British Journal of Political Science 25 no XX (1995): 485-514.

${ }^{30}$ Rachel Cichowski, "Western Dreams, Eastern Realities: Support for the European Union in Central and Eastern Europe," Comparative Political Studies 33 no. 10 (2000): 1243-1278.

${ }^{31}$ Anderson, "When in Doubt"; Piret Ehin, Determinants of Public Support for EU Membership: Data from the Baltic Countries," European Journal of Political Research 40 no. 1 (2001): 31-56; M. Franklin, C. Van der Eijik, and M. Marsh, "Referendum Outcomes and Trust in Government: Public Support for Europe in the Wake of Maastricht," Western European Politics 18 no. 3 (1995): 1101-1117.

${ }^{32}$ I use ordinary least squares regression techniques to estimate the models. Robustness checks indicate that substantive results do not change when I run alternative models or use different coding schemes. 